ALCHEMY Jurnal Penelitian Kimia

Laman resmi: https://jurnal.uns.ac.id/alchemy

\title{
Pengaruh Pemurnian terhadap Kualitas dan Kandungan Skualen Minyak Biji Kemangi Hutan (Ocimum gratissimum L.)
}

\author{
Hartati Soetjipto", Yoga Andika Putra, A. Ign Kristijanto \\ Jurusan Kimia, FSM, Universitas Kristen Satya Wacana, Jl. Ir. Diponegoro 52-60, Salatiga 50711 telp. 082136307858 \\ *Corresponding author: hartati.sucipto@uksw.edu \\ DOI: 10.20961/alchemy.16.2.41110.190-198
}

Received 11 April 2020, Accepted 09 July 2020, Published 01 September 2020

\begin{abstract}
Kata kunci:
ekstraksi;

kemangi;

pemurnian;

skualena.

ABSTRAK. Ocimum gratissimum L. atau kemangi hutan merupakan salah satu jenis tanaman yang banyak dimanfaatkan dalam bidang pengobatan tradisional. Biji dari tanaman kemangi hutan diduga mengandung senyawa aktif antioksidan berupa skualena yang banyak digunakan dalam industri farmasi. Sumber utama senyawa skualena adalah minyak hati ikan hiu, kenyataan ini memperkuat alasan perburuan ikan hiu semakin marak. Skualen nabati yang bisa ditemukan pada beberapa jenis tumbuhan menjadi salah satu alternatif untuk mengurangi penggunaan skualena dari minyak hati ikan hiu. Penelitian ini bertujuan untuk menentukan hasil rendemen, sifat fisiko-kimia serta menganalisa komponen penyusun minyak biji kemangi hutan dengan metode Gas Chromatography-Mass Spectrometry (GC-MS). Tahapan penelitian meliputi ekstraksi minyak biji kemangi hutan menggunakan alat soxhlet dengan pelarut heksana dilanjutkan dengan proses pemurnian yang meliputi degumming dan netralisasi. Tahap terakhir berupa analisa GCMS minyak hasil ekstraksi. Hasil penelitian menunjukkan bahwa rendemen minyak biji kemangi hutan setelah pemurnian diperoleh sebesar 5,106 $\pm 0,10 \%$, berwarna kuning pucat berbau khas kemangi hutan, kadar air minyak $0,06 \%$; massa jenis minyak $0,84 \mathrm{~g} / \mathrm{mL}$; bilangan asam $0,416 \pm 0 \mathrm{mg} \mathrm{KOH} / \mathrm{g}$ minyak; bilangan peroksida $0,028 \pm 0 \mathrm{meq} \mathrm{O}_{2} / \mathrm{g}$ minyak; dan bilangan penyabunan $219,648 \pm 2,608 \mathrm{mg} \mathrm{KOH} / \mathrm{g}$. Sifat fisikokimia tersebut telah memenuhi kriteria SNI. Hasil analisis GC-MS menunjukkan bahwa minyak biji kemangi hutan didominasi oleh empat komponen utama yaitu skualena $(58,85 \%)$, asam propanedioat $(16,69 \%)$, asam palmitat $(14,91 \%)$, dan metil heksanoat $(9,55 \%)$. Pemurnian minyak biji kemangi hutan meningkatkan kandungan skualena dari $1,07 \%$ menjadi $58,85 \%$.
\end{abstract}

Keywords:

extraction;

basil;

extraction;

purification; squalene.

\begin{abstract}
The Effect of Purification on The Quality and Content of Forest Basil Seed Oil (Ocimum gratissimum L.). O. gratissimum L. or forest basil is a plant that is widely used in traditional medicine. Forest basil' seeds suspected contain active antioxidant compounds that have the shape of squalene, and it is widely used in the pharmaceutical industry. The main source of the squalene compound is shark liver oil; this fact reinforces the reason for shark hunting increasingly widespread. Plant Squalene, which can be found in many plant species, is one of an alternative to reduce the use of squalene from shark liver oil. The aims of this work are to determine the yield, physicochemical properties and to analyze the components of forest basil'seed oil using Gas Chromatography-Mass Spectrometry (GC-MS). The stages of this work included extraction of forest basil seeds using Soxhlet extractor in hexane solvent, followed by a refining process includes degumming and neutralization. The final step is analyzed forest' basil seed oil obtained using GC-MS. The results showed that the yield of forest basil seed oil obtained in the amount of $5.106 \pm 0.10 \%$, a pale yellow color, with a specific aroma of basil forests, the water content of $0.06 \%$ oil; oil density $0.84 \mathrm{~g} / \mathrm{mL}$; an acid number of $0.416 \pm 0 \mathrm{mg} \mathrm{KOH} / \mathrm{g}$ of oil; peroxide number of $0.028 \pm 0 \mathrm{meq} \mathrm{O}_{2} / \mathrm{g}$ of oil; and a saponification number of $219.648 \pm 2.608 \mathrm{mg} \mathrm{KOH} / \mathrm{g}$ of oil. The physicochemical properties have fulfilled SNI criteria. GC-MS analysis resulted that forest basil' seeds oil are dominated by four main components, namely squalene $(58.85 \%)$, propanedioic acid (16.69\%), palmitic acid $(14.91 \%)$, and methyl hexanoate $(9.55 \%)$. Purification forest basil seed oil increases squalene of $1.07 \%$ to $58.85 \%$.
\end{abstract}

\section{PENDAHULUAN}

Ocimum gratissimum L. adalah salah satu jenis kemangi dari anggota suku Lamiaceae yang umum dikenal sebagai "kemangi hutan". Kemangi hutan ini sering digunakan dalam ritual keagamaan di beberapa daerah di Indonesia, sehingga tanaman ini juga dikenal sebagai "Selaseh Mekah" (Sulistiarini, 1999). Umumnya kemangi hutan bermanfaat sebagai pereda rasa sakit dan agen anti-inflamasi. Di sisi lain, biji kemangi hutan juga dimanfaatkan sebagai sumber serat makanan serta berbagai pengobatan tradisional (Hashemi et al., 2017). Lebih lanjut menurut Prakash dan Gupta (2000) minyak biji kemangi hutan mengandung antioksidan dan senyawa yang 
dapat meningkatkan kerja enzim hati pada tikus uji. Sedangkan Sukandar et al. (2017) melaporkan bahwa minyak biji kemangi mengandung senyawa aktif antioksidan yang merupakan golongan terpenoid dan fenolik, yaitu skualena.

Skualena merupakan senyawa triterpen yang mengandung enam unit isopren hidrokarbon dengan enam ikatan rangkap yang tidak terkonjugasi $\left(\mathrm{C}_{30} \mathrm{H}_{50}\right)$ (Schneider, 2016). Skualena digunakan dalam industri kosmetika sebagai penghalus kulit dan pelembab (Blasco et al., 2006). Dalam bidang industri farmasi, skualena banyak dimanfaatkan untuk pencegahan kanker dan tumor (Gunes, 2013), serta dalam pembuatan vaksin (Fox, 2009). Kelebihan skualena lainnya adalah sifatnya yang tidak beracun dan tidak memberikan efek samping (Erizal, 2005). Tingginya nilai ekonomi senyawa skualena akan semakin menambah minat untuk berburu hiu, apabila kondisi ini dibiarkan maka populasi ikan hiu khususnya jenis cucut botol akan punah (Bondioli et al., 1993). Hal ini menjadi dasar dilakukannya penelitian mengenai skualena nabati yang diperoleh dari minyak nabati tanaman kemangi hutan.

Dikenal ada beberapa metode untuk mengekstraksi minyak nabati dari kacang-kacangan, yaitu dengan cara pengepresan mekanik, ekstraksi, dan fermentasi (Soeka, 2008). Pada dasarnya ekstraksi yang paling umum digunakan dalam mengekstrak minyak dari biji atau tanaman hasil pertanian adalah dengan cara ekstraksi berkelanjutan menggunakan ekstraktor soxhlet dan maserasi. Pelarut yang umum digunakan berupa pelarut non polar (Soetjipto et al., 2018a). Hasil karakterisasi minyak biji kemangi hutan dipengaruhi oleh banyak faktor, salah satunya adalah pemilihan pelarut yang digunakan pada saat ekstraksi (Sukandar et al., 2017). Selain itu pemilihan metode ekstraksi juga sangat mempengaruhi hasil yang diperoleh. Sehingga dengan metode ekstraksi yang tepat maka akan diperoleh rendemen minyak yang optimal dengan karakteristik yang akurat (Daryono et al., 2014). Minyak kasar yang diperoleh dari hasil ekstraksi masih mengandung "pengotor" seperti gum, protein, resin, dll., sehingga dibutuhkan tahap pemurnian minyak yang meliputi tahap degumming dan netralisasi untuk memperoleh minyak murni. Penggunaan $\mathrm{H}_{3} \mathrm{PO}_{4}$ dalam tahap degumming akan menghilangkan pengotor yang sebelumnya tidak larut dalam air menjadi larut dan hilang dalam proses pencucian. Sedangkan sisa asam dalam minyak akan dinetralkan dalam tahap netralisasi menggunakan $\mathrm{NaOH}$ (Ketaren, 1986).

Kriteria yang harus diperhatikan dalam pemilihan pelarut yang digunakan dalam proses ekstraksi antara lain biaya, sifat fisik, ketersediaan, rendahnya suhu kritis untuk mengurangi biaya pengerjaan, dan reaktivitas. Pelarut yang sering digunakan dalam ekstraksi minyak nabati adalah heksana. Heksana memiliki sifat inert, dapat melarutkan dengan cepat, dan memiliki titik didih yang relatif rendah. Tetapi heksana memiliki toksisitas tinggi menyebabkan euforia ringan yang mengakibatkan kegagalan saraf (Soetjipto et al., 2018b). Sehingga Aziz et al. (2009) menyatakan bahwa etanol lebih dianjurkan sebagai pengganti heksana dalam aplikasinya sebagai pelarut minyak nabati. Pada kenyataannya etanol merupakan pelarut yang sering digunakan dalam produk pangan. Penggunaan pelarut heksana sangat umum digunakan, namun harus dipastikan minyak diuapkan sampai benarbenar bebas heksana. Dalam penelitian ini dipilih etanol 95\% sebagai pembanding heksana untuk mengekstraksi minyak biji kemangi hutan.

Pemanfaatan minyak nabati biji kemangi hutan dalam bidang industri farmasi membutuhkan data ilmiah berupa karakterisasi fisiko-kimia dari minyak biji kemangi hutan sehingga aplikasinya dapat diperluas. Karakterisasi minyak merupakan dasar untuk penentuan lanjutan terkait penelitian, kandungan nutrisi, dan teknologi yang digunakan dalam deteksi pemalsuan produk (Abdillah et al., 2014). Karakterisasi minyak yang dimaksud berupa sifat fisiko-kimia meliputi warna, aroma, massa jenis, rendemen atau yield, kadar air, bilangan asam, bilangan peroksida, bilangan penyabunan, dan analisa dengan menggunakan GC-MS (Soetjipto et al., 2018a).

Berdasarkan latar belakang tersebut maka penelitian ini bertujuan untuk memperoleh rendemen hasil ekstraksi minyak biji kemangi hutan, menentukan sifat fisiko-kimia minyak biji kemangi hutan, dan identifikasi kandungan senyawa utama dalam minyak dengan GC-MS. Keterbaruan dari penelitian ini adalah pengembangan aplikasi dari biji kemangi hutan sebagai minyak nabati. Karena pada penelitian terkait biji kemangi hutan banyak dimanfaatkan dalam pembuatan minyak atsiri dan ekstrak kasar saja.

\section{METODE PENELITIAN}

Bahan kimia dan pelarut yang digunakan dalam penelitian adalah sampel biji kemangi hutan yang diperoleh di Salatiga dan pelarut kimia dengan derajat pro analysis dari Smart Indonesia adalah n-heksana, etanol 95\%, $\mathrm{CH}_{3} \mathrm{COOH}, \mathrm{CHCl}_{3}, \mathrm{HCl}, \mathrm{KI}$, indikator $\mathrm{PP}, \mathrm{Na}_{2} \mathrm{~S}_{2} \mathrm{O}_{3}, \mathrm{KOH}, \mathrm{H}_{3} \mathrm{PO}_{4}$, dan $\mathrm{NaOH}$. Piranti yang digunakan antara lain neraca analitis dengan ketelitian 0,0001 gram (Ohaus PA124, USA), seperangkat alat Soxhlet, waterbath 
(Memmert WNB 14, Memmert gmbh+KG, Germany), $\mathrm{pH}$ meter (Hanna Instrument 9812), rotary evaporator (Buchi R-114, Swiss), grinder (Maspion, Indonesia), dan Gas Chromatography-Mass Spectrometry (Shimadzu, Jepang).

\section{Ekstraksi Minyak Biji Kemangi Hutan}

Biji kemangi hutan dicuci lalu dikeringkan di dalam oven $\left(60^{\circ} \mathrm{C}\right)$, kemudian dihaluskan dengan grinder. Metode ekstraksi dilakukan dengan metode ekxtraksi berkelanjutan biji kemangi hutan dengan piranti soxhlet (Soetjipto et al., 2018a telah dimodifikasi). Biji kemangi hutan sebanyak $100 \mathrm{~g}$ diekstraksi dengan $400 \mathrm{~mL}$ pelarut n-heksana dengan metode ekstraksi berkelanjutan menggunakan ekstraktor soxhlet pada suhu $70{ }^{\circ} \mathrm{C}$ selama $8-$ 10 jam. Hasil ekstrak diuapkan pada suhu $65^{\circ} \mathrm{C}$.

\section{Analisa Sifat Fisiko-Kimia Minyak Biji Kemangi Hutan}

Parameter sifat fisiko-kimia yang diuji meliputi : pengujian bau dan warna secara deskriptif dan penentuan rendemen secara gravimetri; massa jenis; kadar air; bilangan asam; bilangan peroksida; dan bilangan penyabunan.

\section{Rendemen (AOCS Aa 4-38, 1998)}

Rendemen ditentukan dengan neraca analitis (ketelitian 0,0001 gram). Perhitungan rendemen melalui persamaan (1).

$$
\% \text { Rendemen }=\frac{\text { massa minyak }(\mathrm{g})}{\text { massa sampel }(\mathrm{g})} \times 100 \%
$$

\section{Massa Jenis (AOCS Cc 10A-25, 2005)}

Minyak biji kemangi hutan sebanyak $1 \mathrm{~mL}$ ditimbang dengan neraca analitis dan massa jenis dinyatakan dalam $\mathrm{g} / \mathrm{mL}$.

\section{Kadar Air (SNI 01-3555-1998)}

Minyak biji kemangi hutan sebesar 5 gram diukur dan ditimbang, kemudian dimasukkan dalam oven pada suhu $105^{\circ} \mathrm{C}$ selama 30 menit dan didinginkan dalam desikator selama 25 menit, lalu ditimbang. Kadar air dinyatakan dalam persen $(\%)$.

\section{Bilangan Asam (AOCS Ca 5a-40, 1997)}

Sebanyak 0,2 g minyak biji kemangi hutan ditambahkan 2,5 mL etanol 96\% netral panas (dengan $\mathrm{pH} 7 \mathrm{dan}$ suhu $50{ }^{\circ} \mathrm{C}$ ). Larutan dititrasi dengan $\mathrm{NaOH}$ terstandar $0,1 \mathrm{~N}$ dengan penambahan indikator PP. Bilangan asam dihitung dengan persamaan (2).

$$
\text { Bilangan asam }(\mathrm{mgKOH} / \mathrm{g})=\frac{\mathrm{ml} \mathrm{NaOH} \times \mathrm{N} \times \mathrm{Mr} \mathrm{NaOH}}{\text { berat sampel }(\mathrm{g})}
$$

Keterangan :

$$
\begin{array}{ll}
\mathrm{N} & : \text { normalitas } \mathrm{NaOH} \\
\mathrm{Mr} \mathrm{NaOH} & : 39,997 \text { gram } / \mathrm{mol}
\end{array}
$$

\section{Bilangan Peroksida (AOCS Cd 8-53, 1997b)}

Sebanyak 0,2 g minyak biji kemangi hutan dihomogenisasi dengan $2 \mathrm{~mL}$ larutan asam asetat-kloroform (3: $2 \mathrm{v} / \mathrm{v}), 2 \mathrm{~mL} \mathrm{HCl}$ pekat, larutan $\mathrm{KI}$ jenuh, dan $2 \mathrm{~mL}$ akuades dalam erlenmeyer $250 \mathrm{~mL}$. Dititrasi dengan larutan $\mathrm{Na}_{2} \mathrm{~S}_{2} \mathrm{O}_{3}$ 0,001 $\mathrm{N}$ yang terstandarisasi. Dititrasi blanko dengan cara yang sama. Dihitung bilangan peroksida dengan persamaan (3).

$$
\text { Bilangan Peroksida (meq } / \text { Kg minyak })=\frac{(\mathrm{S}-\mathrm{B}) \times \mathrm{N} \times 1000}{\mathrm{~W}}
$$

Keterangan :

$\begin{array}{ll}\mathrm{S} \text { : Volume } \mathrm{Na}_{2} \mathrm{~S}_{2} \mathrm{O}_{3} & 0,001 \mathrm{~N} \text { yang diperlukan untuk titrasi sampel } \\ \mathrm{B} \text { : Volume } \mathrm{Na}_{2} \mathrm{~S}_{2} \mathrm{O}_{3} 0,001 \mathrm{~N} \text { yang diperlukan untuk blanko } & (\mathrm{mL}) \\ \mathrm{N} \text { : Normalitas } \mathrm{Na}_{2} \mathrm{~S}_{2} \mathrm{O}_{3} & (\mathrm{~mL}) \\ \text { W : Berat sampel } & (\mathrm{N})\end{array}$




\section{Bilangan Penyabunan (AOCS Cd 3-25, 2003)}

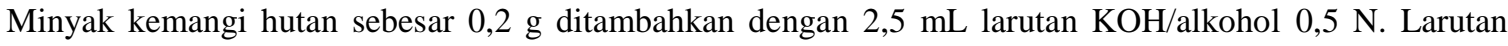
dititrasi dengan $\mathrm{HCl}$ 0,5 N dengan penambahan indikator PP. Blanko ditirasi dengan cara yang sama. Bilangan penyabunan dihitung dengan rumus berikut :

$$
\text { Bilangan penyabunan }=\frac{(B-S) \times N}{\mathrm{~W}} \times 56,1
$$

Keterangan :

$$
\begin{aligned}
\mathrm{B} & =\text { volum } \mathrm{HCl} \text { yang diperlukan untuk titrasi blanko } \\
\mathrm{S} & =\text { volum } \mathrm{HCl} \text { yang diperlukan untuk titrasi sampel } \\
\mathrm{N} & =\text { normalitas larutan } \mathrm{HCl} \\
\mathrm{W} & =\text { bobot sampel }
\end{aligned}
$$

\section{Pemurnian Minyak Biji Kemangi Hutan}

Pemurnian minyak biji kemangi hutan dilalukan dengan proses Degumming (AOCS, 1989 dengan modifikasi). Sebanyak 5 - 15 g minyak biji kemangi hutan ditimbang lalu ditambahkan $\mathrm{H}_{3} \mathrm{PO}_{4} 85 \%$ sebanyak $0,10 \%, 0,15 \%$, dan $0,2 \%$ dari bobot sampel. Campuran dihomogenkan dengan magnetic stirrer pada suhu $75^{\circ} \mathrm{C}$ dan kecepatan $400 \mathrm{rpm}$ selama 45 menit. Campuram didiamkan hingga suhu $\pm 50^{\circ} \mathrm{C}$ dan ditambahkan akuades hangat (suhu $\pm 50^{\circ} \mathrm{C}$ ). Campuran digetarkan kembali pada kecepatan $2.600 \mathrm{rpm}$ selama 10 menit untuk memisahkan gum. Minyak hasil degumming dicuci dengan akuades hingga $\mathrm{pH}$ menjadi 5-5,5.

\section{Proses Netralisasi (AOCS, 1989 dengan modifikasi)}

Minyak biji kemangi hutan hasil degumming ditambah larutan $\mathrm{NaOH} 9,5 \%$ lalu dipanaskan pada suhu $65^{\circ} \mathrm{C}$ selama 30 menit. Campuran dihomogenkan selama 30 menit dengan magnetic stirrer lalu didiamkan hingga suhu $\pm 50{ }^{\circ} \mathrm{C}$ dan ditambahkan akuades hangat (suhu $\pm 50{ }^{\circ} \mathrm{C}$ ), kemudian campuran digetarkan dengan kecepatan 2.600 rpm selama 10 menit. Minyak hasil netralisasi dicuci dengan akuades secara berulang hingga $\mathrm{pH}$ cucian minyak menjadi 7.

\section{Analisa GC-MS}

Analisis komposisi kimia minyak biji kemangi hutan dengan menggunakan Gas Chromatograpy-Mass Spectrometry (GC-MS) dilakukan di Universitas Negeri Semarang, jenis kolom yang digunakan adalah AGILENT\%W DB-I dengan panjang kolom 30 meter dan suhu $65^{\circ} \mathrm{C}$. Suhu injeksi $250^{\circ} \mathrm{C}$ pada tekanan $74,5 \mathrm{kPa}$ dengan total aliran $64,2 \mathrm{~mL} /$ menit, dan kecepatan linier 40,0 cm/detik. ID 0,25 mm dengan gas pembawa Helium dan Pengionan $\mathrm{EI}^{+}$.

\section{HASIL DAN PEMBAHASAN}

\section{Pemurnian Minyak Biji Kemangi Hutan dengan Metode Degumming dan Netralisasi}

Rendemen minyak biji kemangi hutan sebelum dan sesudah pemurnian berturut-turut diperoleh sebesar $17,754 \pm 0,88 \%$ dan $5,106 \pm 0,10 \%$. Data ini menunjukkan adanya penurunan yang cukup besar setelah terjadi pemurnian minyak. Hal ini terkait proses degumming dengan penambahan $\mathrm{H}_{3} \mathrm{PO}_{4}$ yang akan memisahkan getah atupun lendir yang mengandung karbohidrat, protein, polimer, dan fosfolipida. Selain itu senyawa pengotor dan endapan getah proses degumming, larut bersama akuades pada saat pencucian sehingga terjadi pengurangan hasil rendemen minyak (Soetjipto et al., 2018b). Netralisasi juga berpengaruh terhadap terjadinya penurunan nilai rendemen minyak. Penambahan $\mathrm{NaOH}$ pada proses netralisasi akan bereaksi dengan asam lemak bebas sehingga menghasilkan produk berupa sabun. Sabun akan mengikat getah atau lendir yang belum hilang dari proses degumming sehingga rendemen minyak biji kemangi hutan semakin turun (Mardani et al., 2016). Penurunan rendemen minyak yang relatif tinggi sebelum dan sesudah pemurnian menunjukkan minyak biji kemangi hutan mengandung banyak senyawa pengotor yang hilang dalam proses pemurnian.

\section{Profil Fisiko-kimia Minyak Biji Kemangi Hutan (O. gratissimum) Sebelum dan Sesudah Pemurnian}

Gambar minyak biji kemangi hutan sebelum dan sesudah pemurnian dapat dilihat pada Gambar 1. Pengukuran profil fisiko-kimiawi minyak biji kemangi hutan yang meliputi aroma, warna, kadar air, massa jenis, bilangan asam, dan bilangan peroksida sebelum dan sesudah pemurnian berdasarkan 
standar SNI nomor 3741:2013 disajikan dalam Tabel 1.

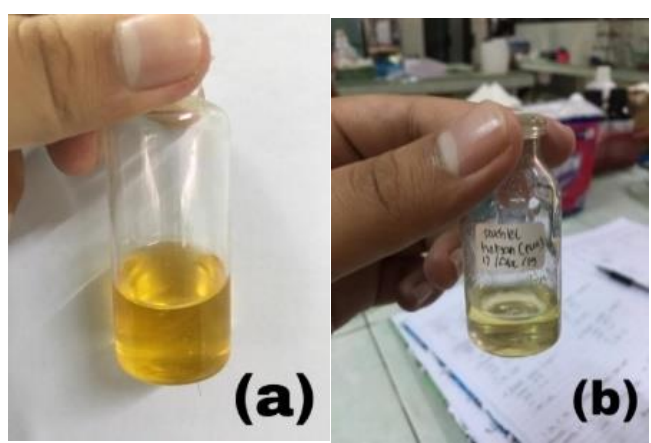

Gambar 1. Minyak biji kemangi hutan (a) sebelum pemurnian dan (b) sesudah pemurnian (sumber: dokumentasi pribadi 2019).

Dari Tabel 1 dapat dilihat bahwa minyak biji kemangi hutan sebelum pemurnian beraroma khas tanaman kemangi hutan dan berwarna jingga. Aroma khas minyak biji kemangi hutan karena adanya senyawa timol. Menurut Matasyoh et al. (2007) senyawa timol dapat memberikan bau aromatik menyegarkan dan juga rasa khas pada minyak biji kemangi hutan. Perubahan warna terjadi pada minyak biji kemangi hutan (Gambar 1(a)) setelah pemurnian menjadi berwarna kuning pucat (Gambar 1(b)) karena pada saat ditambahkan $\mathrm{NaOH}$ akan terjadi pengurangan zat warna pada minyak. Menurut Munawaroh dan Astuti (2010) zat warna cenderung bersifat polar sehingga dapat larut bersama $\mathrm{NaOH}$ dan air pada proses pencucian.

Tabel 1. Perbandingan Profil Fisikokimia Minyak Biji Kemangi Hutan Sebelum dan Sesudah Pemurnian.

\begin{tabular}{|c|c|c|c|}
\hline Parameter & Sebelum Pemurnian & $\begin{array}{l}\text { Setelah } \\
\text { Pemurnian }\end{array}$ & $\begin{array}{l}\text { Standar SNI } \\
3741: 2013 * \\
\text { Minyak Goreng }\end{array}$ \\
\hline Aroma & Bau khas kemangi hutan & $\begin{array}{l}\text { Bau khas kemangi } \\
\text { hutan berkurang }\end{array}$ & Normal \\
\hline Warna & Jingga & Kuning pucat & Kuning pucat-kuning \\
\hline Kadar Air (\% (b/b)) & 0,18 & 0,06 & Maks 0,15 \\
\hline Massa Jenis (g/mL) & 0,84 & 0,84 & - \\
\hline $\begin{array}{l}\text { Bilangan Asam (mg NaOH/g } \\
\text { minyak) }\end{array}$ & $6,24 \pm 0$ & $0,42 \pm 0$ & Maks 0,60 \\
\hline $\begin{array}{l}\text { Bilangan Peroksida (mequiv } \\
\mathrm{O}_{2} / \mathrm{g} \text { minyak) }\end{array}$ & $0,11 \pm 0,01$ & $0,03 \pm 0$ & Maks 1,00 \\
\hline $\begin{array}{l}\text { Bilangan Penyabunan (mg } \\
\mathrm{KOH} / \mathrm{g} \text { minyak) }\end{array}$ & $221,42 \pm 1,04$ & $219,65 \pm 2,61$ & - \\
\hline
\end{tabular}

Beberapa macam pigmen yang umum ditemukan dalam minyak nabati misalnya xanthofil, klorofil, karoten, dan antosianin. Kehadiran pigmen ini menyebabkan minyak berwarna kuning-kuning kecoklatan (Ketaren, 1986). Dari Tabel 1 tampak nilai kadar air minyak biji kemangi hutan menurun setelah proses pemurnian, yaitu dari $0,18 \%$ menjadi $0,06 \%$. Penurunan ini terjadi karena adanya proses pemurnian dan penambahan reagen pengering natrium sulfat anhidrat $\left(\mathrm{Na}_{2} \mathrm{SO}_{4}\right)$ ke dalam minyak hasil pemurnian (Kurniawan et al., 2008). Kadar air dalam minyak sangat berpengaruh terhadap mutu minyak, karena semakin tinggi kadar airnya, semakin mudah minyak mengalami reaksi hidrolisis yang akan menyebabkan kerusakan minyak.

Lebih lanjut proses pemurnian sangat berpengaruh terhadap penurunan nilai beberapa parameter fisikokimiawi minyak biji kemangi hutan yang meliputi nilai bilangan asam, bilangan peroksida, dan bilangan penyabunan. Penurunan nilai bilangan asam pada sampel minyak kemangi hutan dari 6,24 $\pm 0 \mathrm{mg} \mathrm{NaOH} / \mathrm{g}$ minyak menjadi $0,42 \pm 0 \mathrm{mg} \mathrm{NaOH} / \mathrm{g}$ minyak. Untuk parameter bilangan peroksida juga mengalami penurunan setelah proses pemurnian yaitu yang semula $0,11 \pm 0,01$ mequiv $\mathrm{O}_{2} / \mathrm{g}$ minyak menjadi $0,03 \pm 0$ mequiv $\mathrm{O}_{2} / \mathrm{g}$ minyak. Bilangan penyabunan minyak biji kemangi hutan cenderung konstan setelah dilakukannya proses pemurnian yaitu dari 221,42 $\pm 1,04 \mathrm{mg} \mathrm{KOH} / \mathrm{g}$ minyak menjadi 219,65 $\pm 2,61 \mathrm{mg} \mathrm{KOH} / \mathrm{g}$ minyak. Dari hasil analisa profil fisikokimia minyak biji kemangi hutan yang telah dilakukan dapat dikatakan bahwa minyak biji kemangi hutan mengalami peningkatan kualitas minyak dilihat dari parameter kadar air, bilangan asam, bilangan peroksida, dan bilangan penyabunan. Bahkan minyak yang dihasilkan setelah pemurnian memenuhi baku mutu SNI minyak 
goreng No. $3741: 2013$.

Identifikasi Komponen-Komponen Minyak Biji Kemangi Hutan (O. gratissimum L.) dengan (GC-MS) Sebelum dan Sesudah Pemurnian

Hasil analisis komponen penyusun minyak biji kemangi hutan dengan menggunakan Gas ChromatographyMass Spectrometry (GC-MS) sebelum dan sesudah pemurnian disajikan pada Gambar 2 dan Tabel 2. Hasil analisis GC-MS menunjukkan profil asam lemak minyak biji kemangi hutan yang diperoleh dengan ekstraktor soxhlet sebelum proses pemurnian tersusun dari 6 senyawa. Dengan waktu retensi masing-masing 12,$98 ; 14,83 ; 15,45$; 15,96; 16,89; dan 18,30 berturut-turut adalah asam palmitat, skualena, asam stearat, asam oleat, asam linoleat, dan asam linolenat. Sedangkan untuk profil asam lemak minyak biji kemangi hutan sesudah pemurnian tersusun dari 4 senyawa dominan. Dengan waktu retensi masing-masing 12,97; 14,82; 17,77; dan 18,49 berturut-turut adalah asam palmitat, skualena, asam propanedioat, dan metil heksanoat.

Puncak skualena pada Tabel 2 baik sebelum maupun sesudah proses pemurnian mengalami kenaikan pada luas area yang awalnya 1,07\% menjadi 58,85\% menunjukkan bahwa proses pemurnian sangat berpengaruh terhadap kadar senyawa skualena dalam minyak biji kemangi hutan, karena skualen tidak ikut tersabunkan dengan $\mathrm{NaOH}$ pada saat proses netralisasi. Hilangnya pengotor dalam proses pemurnian minyak menghasilkan minyak yang murni dengan kandungan skualena didalamnya, sehingga dalam pengukuran prosentasi skualen meningkat (Musbah et al., 2017). Dari Tabel 2 juga terlihat beberapa senyawa yang mengalami penurunan bahkan hilang setelah pemurnian seperti misalnya asam laurat, decadienal, asam stearat, asam oleat, asam linoleat, dan asam linolenat. Hal ini disebabkan kandungan asam lemak, pengotor, dan logam pada minyak ikut larut bersama $\mathrm{H}_{3} \mathrm{PO}_{4}$ dalam proses degumming serta tersabunkan oleh $\mathrm{NaOH}$ pada tahap netralisasi kemudian larut dalam proses pencucian dengan akuades (Gusti and Zulnely, 2015).

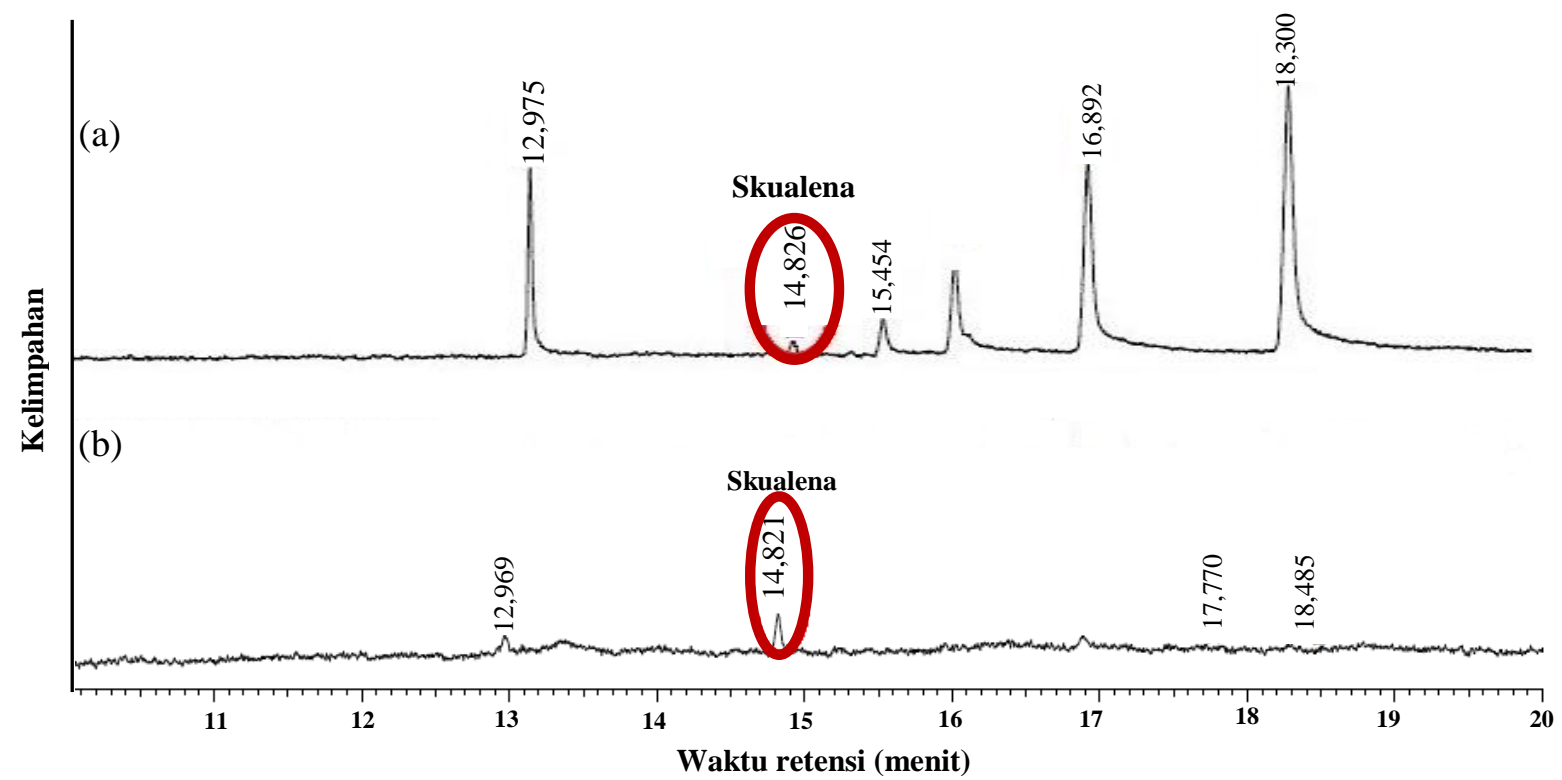

Gambar 2. Kromatogram minyak biji kemangi hutan: (a) sebelum pemurnian dan (b) setelah pemurnian.

Senyawa asam linolenat dan turunannya (asam linoleat dan asam oleat) diduga mengalami reaksi adisi elektrofilik selama proses pemurnian yang dipicu oleh penambahan asam dan suhu larutan yang cukup panas. Akibatnya senyawa tersebut akan terhidrolisis dan memutus ikatan rangkap sehingga menghasilkan senyawa stearat. Reaksi ini menyebabkan munculnya gugus hidrofilik dan berpengaruh pada kepolaran senyawa stearat (Daniel, 2016 dan Mutaqin et al., 2013). Senyawa stearat diduga ikut larut bersama akuades selama proses pencucian sehingga tidak muncul puncak setelah pemurnian. Dua senyawa baru muncul sesudah pemurnian seperti asam propanedioat dan metil heksanoat dengan luas area secara berturut-turut adalah 16,69\% dan 9,55\%. Proses pemurnian menyebabkan beberapa asam lemak dan senyawa pengotor bereaksi dengan $\mathrm{NaOH}$ maupun $\mathrm{H}_{3} \mathrm{PO}_{4}$, sehingga memungkinkan senyawa lain yang semula ada dengan jumlah sedikit dan tidak muncul karena banyaknya pengotor akan muncul sebagai puncak baru setelah pengotor hilang. Dengan kata lain proses pemurnian memungkinkan munculnya puncak baru pada minyak. 
Tabel 2. Profil Asam Lemak Minyak Biji Kemangi Hutan Sebelum dan Sesudah Pemurnian Hasil Analisa GCMS.

\begin{tabular}{|c|c|c|c|c|c|c|}
\hline \multirow[b]{2}{*}{$\begin{array}{l}\text { Nama Komponen (Standar } \\
\text { Internasional) }\end{array}$} & \multirow[b]{2}{*}{$\begin{array}{c}\text { Berat } \\
\text { Molekul }\end{array}$} & \multirow[b]{2}{*}{$\begin{array}{c}\text { Rumus } \\
\text { Molekul }\end{array}$} & \multicolumn{2}{|c|}{ Sebelum Pemurnian } & \multicolumn{2}{|c|}{ Setelah Pemurnian } \\
\hline & & & $\begin{array}{c}\text { Waktu } \\
\text { Retensi } \\
\text { (menit) }\end{array}$ & $\%$ Area & $\begin{array}{l}\text { Waktu } \\
\text { Retensi } \\
\text { (menit) }\end{array}$ & $\%$ Area \\
\hline $\begin{array}{l}\text { Dodecanoic acid, methyl ester } \\
\text { (CAS) (asam laurat) }\end{array}$ & 214 & $\mathrm{C}_{13} \mathrm{H}_{26} \mathrm{O}_{2}$ & 7,51 & 0,45 & - & - \\
\hline $\begin{array}{l}\text { 2,4-Decadienal, (E,E)- (CAS) } \\
\text { trans,trans (decadienal) }\end{array}$ & 152 & $\mathrm{C}_{10} \mathrm{H}_{16} \mathrm{O}$ & 7,63 & 0,42 & - & - \\
\hline $\begin{array}{l}\text { Hexadecanoic acid (CAS) } \\
\text { (asam palmitat) }\end{array}$ & 256 & $\mathrm{C}_{16} \mathrm{H}_{32} \mathrm{O}_{2}$ & 12,98 & 14,76 & 12,97 & 14,91 \\
\hline $2,6,10,14,18,22$ & & & & & & \\
\hline $\begin{array}{l}\text { Tetracosahexaene } \\
\text { (skualena) }\end{array}$ & 410 & $\mathrm{C}_{30} \mathrm{H}_{50}$ & 14,83 & 1,07 & 14,82 & 58,85 \\
\hline $\begin{array}{l}\text { Octadecanoic acid (CAS) } \\
\text { (asam stearat) }\end{array}$ & 284 & $\mathrm{C}_{18} \mathrm{H}_{36} \mathrm{O}_{2}$ & 15,45 & 3,44 & - & - \\
\hline $\begin{array}{l}\text { Octadec-9-Enoic acid } \\
\text { (asam oleat) }\end{array}$ & 282 & $\mathrm{C}_{18} \mathrm{H}_{34} \mathrm{O}_{2}$ & 15,96 & 11,39 & - & - \\
\hline $\begin{array}{l}\text { 9,12-Octadecadienoic acid } \\
\text { (Z,Z) } \\
\text { (asam linoleat) }\end{array}$ & 280 & $\mathrm{C}_{18} \mathrm{H}_{32} \mathrm{O}_{2}$ & 16,89 & 26,92 & - & - \\
\hline $\begin{array}{l}\text { Propanedioic acid, 2- } \\
\text { propenyl-, diethyl e (asam } \\
\text { propanedioat) }\end{array}$ & 200 & $\mathrm{C}_{10} \mathrm{H}_{16} \mathrm{O}_{4}$ & - & - & 17,77 & 16,69 \\
\hline $\begin{array}{l}9,12,15 \text {-Octadecatrienoic } \\
\text { acid, methyl es (asam } \\
\text { linolenat) }\end{array}$ & 292 & $\mathrm{C}_{19} \mathrm{H}_{32} \mathrm{O}_{2}$ & 18,30 & 41,55 & - & - \\
\hline $\begin{array}{l}\text { 4-D1-5-D2 methyl 2- } \\
\text { hexenoate (metil heksanoat) }\end{array}$ & 128 & $\mathrm{C}_{7} \mathrm{H}_{12} \mathrm{O}_{2}$ & - & - & 18,49 & 9,55 \\
\hline TOTAL & & & & 100 & & 100 \\
\hline
\end{tabular}

\section{KESIMPULAN}

Proses pemurnian sangat berpengaruh terhadap kualitas dan kandungan skualen minyak biji kemangi hutan. Sifat fisikokimia minyak biji kemangi hutan setelah pemurnian mengalami perbaikan karena memenuhi kriteria SNI, sedangkan kandungan skualen mengalami peningkatan dari 1,07\% menjadi 58,85\%.

\section{UCAPAN TERIMA KASIH}

Ucapan terima kasih ditujukan kepada Kemenristekdikti atas pembiayaan penelitian ini melalui Dana Hibah Program PDU PT periode 2019/2020.

\section{DAFTAR PUSTAKA}

Abdillah, M.N., Musfiroh, I., and Indriyati, W., 2018. Analisis Senyawa Antioksidan Pada Minyak Biji Labu Kuning (Cucurbita pepo L .). Taksonomi Tumbuhan Jurusan Biologi Fakultas MIPA Universitas Padjadjaran 1(2), 53-61.

American Oil Chemists' Society Champaign. 1989. Official Methods and Recommended Practices of the American Oil Chemists' Society.

American Oil Chemists' Society Champaign. 1997a. Official Methods and Recommended Practices of the American Oil Chemists' Society (p. Ca 5a-40).

American Oil Chemists' Society Champaign. 1997b. Official Methods and Recommended Practices of the American Oil Chemists' Society (p. Cd 8-53).

American Oil Chemists' Society Champaign. 1998a. Official Methods and Recommended Practices of the 
American Oil Chemists' Society (p. Aa 4-38).

American Oil Chemists' Society Champaign. 2003. Official Methods and Recommended Practices of the American Oil Chemists' Society (p. Cd 3-25).

American Oil Chemists' Society Champaign. (2005. Official Methods and Recommended Practices of the American Oil Chemists' Society (p. Cc 10A-25).

Azis, T., Cindo R. K. N., and Fresca A., 2009. Pengaruh Pelarut Heksana dan Etanol, Volume Pelarut, dan Waktu Ekstraksi terdapat Hasil Ekstraksi Minyak Kopi. Jurnal Teknik Kimia 16(1), 1-8.

Blasco, L., Duracher, L., Forestier, J.P., Vian, L., and Marti-Mestres, G., 2006. Skin Constituents as Cosmetic Ingredients. Part I: A Study of Bio-mimetic Monoglycerides Behavior at the Squalene-Water Interface by the "Pendant Drop" Method in a Static Mode. Journal of Dispersion Science and Technology 27(6), 799-810. doi: 10.1080/01932690500482137.

Bondioli, P., Mariani, C., Lanzani, A., Fedeli, E., and Muller, A., 1993. Squalene Recovery from Olive Oil Deodorizer Distillates. Journal of the American Oil Chemists Society 70(8), 763-766. doi: 10.1007/BF02542597.

Daniel., 2016. Peningkatan Kepolaran Asam Linoleat Dalam Bentuk Amida Menjadi N-etanol-9,10,12,13,15,16 Heksahidroksi Oleil-Amida. Jurnal Kimia Mulawarman Volume 13 Nomor 2 Mei 2016.

Daryono E.D., Pursitta A.T., and Isnaini A., 2014. Ekstraksi Minyak Atsiri pada Tanaman Kemangi dengan Pelarut n-Heksana. Jurnal Teknik Kimia 9(1), 1-7.

Erizal., 2005. Sintesis dan Karakterisasi Squalene- TMPT Hasil Iradiasi Gamma. Prosiding Simposium Nasional Polimer V, 105-110.

Fox, C.B., 2009. Squalene Emulsions for Parenteral Vaccine and Drug Delivery. Molecules 14(9), 3286-3312. doi: 10.3390/molecules14093286.

Gunes, F. E., 2013. Medical Use of Squalene as a Natural Antioxidant. Journal of Marmara University Institute of Health Sciences 3(4), 220-228. doi: 10.5455/musbed.20131213100404.

Gusti, R.E.P. and Zulnely, Z., 2015. Pemurnian Beberapa Jenis Lemak Tengkawang dan Sifat Fisiko Kimia. Jurnal Penelitian Hasil Hutan 33(1), 61-68. doi: 10.20886/jphh.2015.33.1.61-68.

Hashemi, G.H., Ziaee, E., Eskandari, M.H., and Hosseini, S.M.H., 2017. Characterization of Basil Seed Gumbased Edible Films Incorporated with Zataria multiflora Essential Oil Nanoemulsion. Carbohydrate Polymers 166, 93-103. doi: 10.1016/j.carbpol.2017.02.103.

Ketaren, S., 1986. Pengantar Teknologi Minyak dan Lemak Pangan. UI-Press., Jakarta.

Kurniawan, A., Chandra, Indraswati, N., and Mudjijati., 2008. Ekstraksi Minyak Kulit Jeruk dengan Metode Distilasi, Pengepresan dan Leaching. Widya Teknik 7(1), 15-24. doi: 10.33508/wt.v7i1.1257.

Mardani, S., Ghavami, M., Heidary-Nasab, A., and Gharachorloo, M., 2016. The Effects of Degumming and Neutralization on the Quality of Crude Sunflower and Soyabean Oils. Journal of Food Biosciences and Technology 6(2), 47-52.

Matasyoh, L. G., Matasyoh, J.C., Wachira, F.N., Kinyua, M.G., Thairu Muigai, A.W., and Mukiama, T. K., 2007. Chemical Composition and Antimicrobial Activity of the Essential Oil of Ocimum gratissimum L. Growing in Eastern Kenya. African Journal of Biotechnology 6(6), 760-765. doi: 10.5897/AJB2007.000-2085.

Munawaroh, S. and Astuti, P., 2010. Ekstraksi Minyak Daun Jeruk Purut (Citrus hystrix D.C.) dengan Pelarut Etanol dan N-Heksana. Jurnal Kompetensi Teknik 2(1), 73-78.

Musbah, M., Suseno, S.H., and Uju, S., 2017. Kombinasi Minyak Ikan Sardin dan Cucut Kaya Omega 3. Jurnal Pengolahan Hasil Perikanan Indonesia 20(1), 45-52. doi: 10.17844/jphpi.2017.20.1.44.

Mutaqin, A., Sayekti, E., and Destiarti, L., 2013. Identifikasi Hasil Reaksi Adisi Nukleofilik Sianida Pada Gugus Karbonil Sitronelal Menggunakan Pereaksi Kalium Sianida. Jurnal Kimia Katulistiwa 2(1), 38-41.

Prakash, J. and Gupta, S.K., 2000. Chemopreventive Activity of Ocimum sanctum Seed Oil. Journal of Ethnopharmacology 72(1-2), 29-34. doi : 10.1016/S0378-8741(00)00194-X.

Schneider, S., 2016. Quality Analysis of Extra Virgin Olive Oils - Part 5 Nutritive Benefits - Determination of Squalene in Virgin Olive Oil. Agilent Technologies, Inc. Waldbronn, Germany. doi: 10.1007/s12161-0160697-x.

SNI 01-3555-1998 dalam Standar Nasional Indonesia, Cara Uji Minyak dan Lemak.

Soeka, Y.S., 2008. Extraction of Vegetable Oil by Fermentation. Berita Biologi 9(3), 325-332.

Soetjipto, H., Anggreini, T., and Cahyanti, M.N., 2018a. Profil Asam Lemak dan Karakterisasi Minyak Biji Labu Kuning (Cucurbita moschata D.). Jurnal Kimia Dan Kemasan 40(2), 79-86. doi : 10.24817/jkk.v40i2.3797.

Soetjipto, H., Tindage, A., and Cahyanti, M. N., 2018b. Pengaruh Pemurnian Degumming dan Netralisasi terhadap 
Profil Minyak Biji Labu Kuning (Cucurbita Moschata D.). Jurnal Konversi Universitas Muhammadiyah Jakarta 7(1), 49-56. doi : 10.24853/konversi.7.1.8.

Sukandar, D., Hermanto, S., Amelia, E.R., and Novianti, C.P. 2017. Karakterisasi Fraksi Aktif Antioksidan dari Ekstrak Etanol Biji Kemangi (Ocimum Basilicum L.). Jurnal Kimia VALENSI 1(1), 39-49. doi : 10.15408/jkv.v0i0.3598.

Sulistiarini, D., 1999. Ocimum gratissimum L. In: Oyen, L.P.A., Dung Nguyen Xuan (Editors): Plant Resources of South-East Asia No. 19 (1). Medicinal and poisonous plants 1. pp. 140-141.

Tarigan, D., 2016. Peningkatan Kepolaran Asam Linoleat Dalam Bentuk Amida Menjadi N-etanol-9, 10, 12, 13, 15, 16 Heksahidroksi Oleil-Amida. Jurnal Kimia Mulawarman 13(2), 109-113. 